\title{
Planting sweet sorghum under hot and dry climatic condition for bioethanol production
}

\author{
A. Almodares ${ }^{*}$, M.S. Hatamipour \\ University of Isfahan, Isfahan, Iran \\ *Corresponding author. Tel: +98-311-2369005, Fax: +98-311-2344761,E-mail: aalmodares@yahoo.com
}

\begin{abstract}
Plants are the best choice for meeting the projected bio-ethanol demands.For this scope, a comparative analysis of the technological options using different feed stocks should be performed. Sweet sorghum can be used as a feedstock for ethanol production under hot and dry climatic conditions. Because, it has higher tolerance to salt and drought comparing to sugarcane and corn that are currently used for bio-fuel production in the world. In addition, high carbohydrates content of sweet sorghum stalk are similar to sugarcane but its water and fertilizer requirements are much lower than sugarcane. Also, sugarcane is not a salt tolerant plant. On the other hand, high fermentable sugar content in sweet sorghum stalk makes it to be more suitable for fermentation to ethanol.In this work, planting sweet sorghum in hot and dry provinces of Iran generally produced 80 tons stalks, 5 tons grains and 15 tons green leaves per hectare. However comparison among 29 sweet sorghum cultivars and lines showed that Rio had higher biomass (117.14t/ha), stalk yield (95.00t/ha), grain yield (5.00t/ha) and leaves $(17.00 \mathrm{t} / \mathrm{ha})$. It is interesting to point out that sweet sorghum could be cultivated in southern parts of Iran 3-4 times per year. Based on these results it is more economical to plant sweet sorghum for bio-ethanol production in hot and dry regions of the world.
\end{abstract}

Keywords: Sweet sorghum, carbohydrate, bio-ethanol, bio-fuel.

\section{Introduction}

Due to the diminishing fossil fuel reserves, alternative energy sources need to be renewable, sustainable, efficient, cost effective and safe [1]. Ethanol is one of the best renewable source that has all the above characteristics. Ethanol produced from starch hydrolysis and sugar fermentation from biomass is called bio-ethanol. The raw materials used in the ethanol production by fermentation can be classified into three main types of materials, which are sugars, starches and ligno-cellulose. Sugar can be converted into ethanol directly. Starch could be hydrolyzed to fermentable sugars by enzymes; and lingo-cellulose following pretreatment by acids or alkali could be hydrolyzed to sugars. Industrial bio-ethanol is produced from various crops like sugarcane or sugar beet molasses, corn starch, sweet sorghum, tapioca etc. Among them sweet sorghum has been considered as one of the most promising crop for energy and industry in hot and dry climates. Sweet sorghum (Sorghum bicolor L.Moench) is a $\mathrm{C}_{4}$ plant characterized by high biomass and sugar -yielding and a high photosynthetic efficiency [2,3]. It also has a rapid growth rate as it has a shorter growing season than sugarcane and therefore suitable to be grown in most parts of the world. It is well adapted to drought [4] and has the capability of remaining dormant during the driest period Sweet sorghum is the only plant that all parts of plant can be used for bio-ethanol production. Its stalk has sucrose, glucose and fructose readily fermented to ethanol. Its grain flowing starch hydrolysis to glucose could be fermented to ethanol. Sweet sorghum leaves and bagasse as lingo-cellulosic feed-stocks have the greatest potential to be used as second generation of biofuel production. The conversion of sweet sorghum leaves and bagasse to bio-ethanol requires pretreatment to break down the lingo-cellulosic structure, remove lignin and hydrolyze the cellulose and hemicellulose components to sugars. Sugars are converted to biofuel through fermentation. However conversion of lingo-cellulosic feed-stocks to bio-ethanol is not commercialized yet and it is a renewable energy for the future.Most part of Iran has hot and dry climatic condition and due to this condition, corn and wheat is imported. Sugar beet and sugar cane molasses are not in large quantities so the ethanol produced from these 
substrates is supplied by industries. The purpose of this study was to plant sweet sorghum under Iran hot and dry climatic condition and produce bio-ethanol to be mixed with fuel.

\section{Comparisons among sweet sorghum cultivars and lines}

The purpose of this experiment was to determine the most adapted sweet sorghum cultivars and lines under hot and dry condition. 29 sweet sorghum cultivars and lines were compared in a randomized complete block design at the University of Isfahan Experiment Station and University of Isfahan Chemical engineering Lab. Plots consisted of 4 rows, $10 \mathrm{~m}$ apart and $0.75 \mathrm{~m}$ apart. Plots received $300 \mathrm{~kg} / \mathrm{ha}$ of di-ammonium phosphate and $100 \mathrm{~kg} / \mathrm{ha}$ of urea disked into the soil before planting. Water was applied as needed. When kernels were at physiological maturity, three meters form two central rows were harvested. Biomass and stripped stalks were determined. The fresh stalk, after removing the leaves was crushed in a sugarcane crusher to extract the juice. After filtration through a sieve to remove the chaff etc. the soluble solids (brix), sucrose (pol\%) and the purity of the juice were measured according to Varma [5]. Statistical analyses were performed using Statistical Analysis System (SAS) computer program. The means were compared according to Turkey’s test.

\section{Results and Discussion}

\subsection{Weather Information.}

Iran has an arid climate with average annual precipitation of $250 \mathrm{~mm}$ or less. There is no summer rain and this low amount of rain precipitates from October to April when sugar crops such as corn, sorghum, sugar beet and sugar cane are not growing. Therefore all these crops should be irrigated from planting to harvest. Optimum temperature for sweet sorghum germination and growth is above 18 oC. Since sweet sorghum is a warm season crop, so its growth will be reduced considerably when temperature falls below 5 degree centigrade. Table 1 shows the planting date of different provinces of Iran. Sweet sorghum duration from planting to harvest is $120-150$ days. So in Southern part of Iran when the growing season is long (Table2), sweet sorghum can be planted two to three times per year.

\subsection{Comparison among sugarcane, sugar beet and sweet sorghum.}

Among sugar and starch crops that is used for ethanol production in other countries, in Iran ethanol only is produced from sugarcane and sugar beet molasses.

In comparison to other two crops, sweet sorghum has the least crop duration, growing season, soil water requirements, water management and crop management (Table 3). Under Iran climatic condition sweet sorghum has similar biomass, sugar content, sugar yield and ethanol production to sugar cane. It should be mentioned that sugar cane can only be grown in the sought where there is no freeze temperature, whereas sweet sorghum is grown in most part of the country. Based on the above results it is recommended to plant sweet sorghum for ethanol production [6]. 
Table 1. The planting date of different provinces of Iran for sweet sorghum

\begin{tabular}{ccc}
\hline State & Above $\mathbf{1 5}{ }^{\mathbf{0}} \mathbf{C}$ & Less than 0 ${ }^{\mathbf{0}} \mathbf{C}$ \\
Bandar Abbas & Feb. & - \\
\hline Dezful & April & - \\
\hline Isfahan & May & Dec. \\
\hline Kerman & June & Nov. \\
\hline Rasht & May & - \\
\hline Shiraz & May & Dec. \\
\hline Uromieh & Apr. & Nov. \\
\hline Yazd & May & Dec. \\
\hline Zahedan & Apr. & Dec. \\
\hline
\end{tabular}

Table 2. Climatic conditions of Kahnooj

\begin{tabular}{cccc}
\hline Month & $\begin{array}{c}\mathbf{T}_{\max } \\
\left.\mathbf{(}^{\mathbf{0}} \mathbf{C}\right)\end{array}$ & $\left.\mathbf{T}_{\min } \mathbf{(}^{\mathbf{0}} \mathbf{C}\right)$ & $\begin{array}{c}\text { Relative } \\
\text { Humidity (\%) }\end{array}$ \\
Jan. & 21.1 & 8.7 & 70.1 \\
\hline Feb. & 21.0 & 11.7 & 72.0 \\
\hline Mar. & 27.3 & 14.5 & 60.3 \\
\hline Apr. & 32.2 & 18.7 & 60.1 \\
\hline May & 40.5 & 24.8 & 40.0 \\
\hline June & 44.4 & 29.8 & 38.9 \\
\hline July & 45.4 & 30.0 & 42.0 \\
\hline Aug. & 44.0 & 30.0 & 45.9 \\
\hline Sep. & 40.7 & 30.3 & 46.0 \\
\hline Oct. & 38.7 & 23.5 & 53.0 \\
\hline Nov. & 30.5 & 17.0 & 66.0 \\
\hline Dec. & 24.0 & 11.4 & 64.0 \\
\hline
\end{tabular}


Table 3.Comparison among sugarcane, sugar beet and sweet sorghum [6]

\begin{tabular}{cccc}
\hline Crop duration & About 7 months & About 5-6 months & $\begin{array}{c}\text { Sweet sorghum } \\
\text { About 4 months }\end{array}$ \\
\hline Growing season & Only one season & Only one season & $\begin{array}{c}\text { One season in } \\
\text { temperate and two or } \\
\text { three seasons in } \\
\text { tropical areas }\end{array}$ \\
\hline Soil requirement & $\begin{array}{c}\text { Grows well in drain } \\
\text { soil }\end{array}$ & $\begin{array}{c}\text { Grows well in sandy } \\
\text { loam; also tolerates } \\
\text { alkalinity }\end{array}$ & $\begin{array}{c}\text { All types of drained } \\
\text { soil }\end{array}$ \\
\hline Water management & $36000 \mathrm{~m}^{3} / \mathrm{ha}$ & $18000 \mathrm{~m}^{3} / \mathrm{ha}$ & $12000 \mathrm{~m}^{3} / \mathrm{ha}$ \\
\hline Crop management & $\begin{array}{c}\text { Requires good } \\
\text { management }\end{array}$ & $\begin{array}{c}\text { Greater fertilizer } \\
\text { requirement; requires } \\
\text { moderate } \\
\text { management }\end{array}$ & $\begin{array}{c}\text { Little fertilizer } \\
\text { required; less pest } \\
\text { disease complex; } \\
\text { easy management }\end{array}$ \\
\hline Yield per ha & $70-80$ tons & $30-40$ tons & $54-69$ tons \\
\hline $\begin{array}{c}\text { Sugar content on } \\
\text { weight basis }\end{array}$ & $10-12 \%$ & $15-18 \%$ & $7-12 \%$ \\
\hline Sugar yield & $7-8$ tons/ha & $5-6$ tons/ha & $6-8$ ton/ha \\
\hline $\begin{array}{c}\text { Ethanol production } \\
\text { directly from juice }\end{array}$ & $3000-5000 \mathrm{~L} / \mathrm{ha}$ & $5000-6000 \mathrm{~L} / \mathrm{ha}$ & $3000 \mathrm{~L} / \mathrm{ha}$ \\
\hline Harvesting & Mechanical harvest & $\begin{array}{c}\text { Very simple; } \\
\text { normally manual }\end{array}$ & $\begin{array}{c}\text { Very simple; both } \\
\text { manual and } \\
\text { mechanical }\end{array}$ \\
\hline & & &
\end{tabular}

\subsection{Energy balance}

Among feedstock that currently are used in different countries for bio- ethanol production reported sweet sorghum has the highest energy output/input (Table 4). Wheat in Canada has the lowest energy input/output (1.2) while sweet sorghum in temperate areas has the highest output/input (12-16) [7]. Most parts of Iran have high day and low night temperature. During the day because of high temperature through photosynthesis more carbohydrates will be accumulated. Cool nights cause respiration to be decreased. As a result, higher sweet sorghum biomass and sugar will be produced.

Table 4. Energy output/input for different feedstock

\begin{tabular}{ll} 
Feed stock & Energy output/input \\
\hline Sugarcane (Brazil) & 8.3 \\
\hline Sugar beet (European Union) & 1.9 \\
\hline Corn (United States) & $1.3-1.8$ \\
\hline Wheat (Canada) & 1.2 \\
\hline Fossil- fuels & 0.8 \\
\hline Sweet sorghum & $8(12-16$ in temperate ares) \\
\hline
\end{tabular}




\subsection{Comparison among 29 sweet sorghum cultivars and lines for stem yield, brix and sucrose content.}

Mean comparisons are presented in Table 5. Since both stem yield and brix has more important role in ethanol production from sweet sorghum, therefore cultivars and lines have that more than 60t/ha stalk yield and brix more than $20 \%$ were selected. These cultivars are Vespa, MN1500, Soave, Sofra, SSV108, SSV94, SSV96, Foralco and Rio. A further selection among these cultivars indicated that Rio had the highest stalk yield (95 t/ha) and highest brix (22.36). Although the stem yield of M81-E, Theis and Wray was more than $100 \mathrm{t} / \mathrm{ha}$ but their brix was lower than Rio. None of the sweet sorghum lines due to their low stem yield and brix were suitable for ethanol production.[8].

Table 5. Mean comparisons among 29 sweet sorghum cultivars and lines regarding stem yield, ${ }^{\circ} \mathrm{Brix}$, Sucrose and purity at university of Isfahan, Iran [8].

\begin{tabular}{|c|c|c|c|c|}
\hline Genotypes & Stem yield (t/ha) & Brix (\%) & Sucrose (\%) & Purity (\%) \\
\hline \multicolumn{5}{|l|}{ Cultivars } \\
\hline Roce & 39.14 & 21.96 & 14.39 & 66.71 \\
\hline Vespa & 84.53 & 20.99 & 13.05 & 74.59 \\
\hline Brandes & 77.14 & 18.72 & 8.92 & 46.39 \\
\hline MN1500 & 83.71 & 20.71 & 12.00 & 57.59 \\
\hline E36-1 & 48.00 & 18.26 & 13.41 & 76.02 \\
\hline Soave & 61.57 & 20.73 & 13.46 & 65.00 \\
\hline M81-E & 103.57 & 16.01 & 10.26 & 65.10 \\
\hline Somac & 44.43 & 21.12 & 12.85 & 60.10 \\
\hline Sofrah & 85.57 & 19.63 & 12.61 & 64.05 \\
\hline SSV-108 & 62.85 & 22.25 & 13.97 & 62.26 \\
\hline SSV-94 & 70.14 & 20.64 & 11.75 & 57.12 \\
\hline SSV-96 & 62.00 & 22.54 & 13.71 & 60.10 \\
\hline Theis & 100.14 & 19.10 & 7.26 & 37.59 \\
\hline Foralco & 97.71 & 20.40 & 12.64 & 60.83 \\
\hline Rio & 95.00 & 22.36 & 16.06 & 71.31 \\
\hline S-35 & 58.43 & 19.78 & 11.58 & 58.75 \\
\hline Turno & 39.86 & 11.16 & 6.00 & 35.86 \\
\hline Satiro & 27.86 & 17.16 & 10.33 & 60.02 \\
\hline Wray & 126.42 & 15.84 & 7.85 & 49.40 \\
\hline \multicolumn{5}{|l|}{ Lines } \\
\hline IS 686 & 61.43 & 16.54 & 9.00 & 54.39 \\
\hline IS 16054 & 51.85 & 21.07 & 11.73 & 55.83 \\
\hline IS 18154 & 42.14 & 19.04 & 12.71 & 66.71 \\
\hline IS 6962 & 43.00 & 23.01 & 13.61 & 58.85 \\
\hline IS 9639 & 54.00 & 21.77 & 14.31 & 65.23 \\
\hline IS 2325 & 59.57 & 20.70 & 14.28 & 60.18 \\
\hline IS 6973 & 33.43 & 22.85 & 14.21 & 61.88 \\
\hline IS 4546 & 56.43 & 22.03 & 13.05 & 60.12 \\
\hline IS 19273 & 46.28 & 20.29 & 15.04 & 73.69 \\
\hline IS 4354 & 33.86 & 17.66 & 9.80 & 55.28 \\
\hline $\mathrm{W}^{1}$ & 2.53 & 6.18 & 5.05 & 23.981 \\
\hline
\end{tabular}

${ }^{1}$.Tukey's value for $5 \%$ level 


\section{Conclusions}

It is clear that fuel ethanol from sweet sorghum is the best choice to be implement under hot and dry climatic conditions regarding both economic and environmental considerations. Because, sweet sorghum has higher tolerance to drought [9], water logging and salt [10, 11], alkali and aluminum soils; It may be harvested 3 - 4 months after planting (Table 1) and planted 1 - 2 times a year (in tropical areas); Its energy output / fossil energy input is higher than sugarcane, sugar beet, corn, wheat and etc... specially in temperate areas; It is more water use efficient (1/3 of water used by sugarcane at equal sugar production); Its production can be completely mechanized and its bagasse has higher nutritional value than the bagasse from sugarcane, when used for animal feeding. Also, by implementing agricultural practices such as adequate water and fertilizers, suitable cultivars or hybrids, crop rotation, pest management and etc... can increase productivity with focus on bio-fuel production [12].

In addition, sweet sorghum has high amount of sucrose [8] and invert sugar [13] which are easily converted to ethanol $[14,15]$. Therefore, it seems that sweet sorghum is the most suitable crop for bio-fuel production in arid regions of the world. This awareness should push government of the countries with such climatic conditions to promote the development of projects for fuel ethanol production from sweet sorghum. However, social aspects (including environmental concerns) should play a more significant role in the selection of the most suitable feed-stocks for the alcohol industry. In this way, financial indicators would not be necessarily the decisive factors when new large-impact projects for bio-fuels production are studied and implemented in developing countries.

\section{References}

[1] L.H. Chum, R.P. Overend. Biomass and renewable fuels, Fuel Bioprocess Technology 17, 2001, 187-195.

[2] W.L., Bryan, Solid state fermentation of sugars in sweet sorghum. Enzyme Microb. Technol., 12, 1990, 437-442.

[3] E. Billa, D.P. Koullas, B. Monties and E.G. Koukios, Structure and composition of sweet sorghum stalk components. Ind. Crops Prod., 6, 1997, 297-302.

[4] N. Kosaric, Vardar-Sukan, Potential Source of Energy and Chemical Products. In: The Biotechnology of Ethanol: Classical and Future Applications, Roehr, M. (Ed.). WileyVCH, Weinheim, 2001.

[5] N.C. Varma, System of technical control for cane sugar factories in India. The sugar Technologist's Associations. India, 1988.

[6] A. Almodares, M.R. Hadi. Production of bioethanol from sweet sorghum: A revies. Afr.J. Agric.Res. 4, 2009, 772-780.

[7] H.Shapouri, M. Salassi and J.N. Fairbank. The economic feasibility of ethanol production from sugar in the United State. Washington, office of Energy Policy and new uses, office of the chief economist, United State Department of Agriculture, Baton Roughe, Louisiana State University. 2006.

[8] A. Almodares,A. Sepahi, Comparison among sweet sorghum cultivars, lines and hybrids for sugar production. Ann. Plant Physiol. 10, 1996, 50-55. 
[9] T.T. Tesso, L.E.Claflin, M.R. Tuinstra, Analysis of Stalk Rot Resistance and Genetic Diversity among Drought TolerantSorghum Genotypes. Crop Sci. 45, 2005, 645-652.

[10] A, Almodares, M,R. Hadi, H. Ahmadpour, Sorghum stem yield and soluble carbohydrates under phonological stages and salinity levels Afr. J. Biotech. 7, 2008, 4051-4055.

[11] A, Almodares, M,R. Hadi, B.Dosti, The effects of salt stress on growth parameters and carbohydrates contents in sweet sorghum. Res. J. Environ. Sci. 2, 2008a, 298-304.

[12] B.V.S. Reddy, S,Ramesh, P.S. Reddy, B. Ramaiah, P.M. Salimath, R. Kachapur, Sweet Sorghum-A Potential Alternate Raw Material for Bio-ethanol and Bio-energy. Int. Sorghum Millets Newslett. 46, 2005, 79-86.

[13] A. Almodares, R.Taheri, S. Adeli, Stalk yield and carbohydrate composition of sweet sorghum [Sorghum bicolor (L.)Moench] cultivars and lines at different growth stages. J. Malesian Appl. Biol. 37, 2008b, 31-36.

[14] K. Jacques, T.P. Lyons, D.R.Kelsall, The Alcohol Textbook. 3rd Eds. Nottingham Univesity Press.1999, P. 388.

[15] S. Prasad, A. Singh,N. Jain, H.C. Joshi, Ethanol production from sweet sorghum syrup for utilization as automotive fuel in India. Energy Fuels 21, 2007, 2415-2420. 